\title{
Why Rent Control Is Still a Regulatory Taking
}

\author{
by \\ R. S. Radford \\ Pacific Legal Foundation \\ Program for Judicial Awareness \\ Working Paper No. 05-0001
}

A previous draft of this article was presented at Georgetown Environmental Law \& Policy Institute's 7th Annual Conference on Litigating Takings, held at UCLA Law School, October 14-15, 2004. 


\begin{abstract}
The Supreme Court has repeatedly declared that land-use regulations that fail to substantially advance legitimate state interests violate the Takings Clause of the Fifth Amendment. This standard seems readily applicable to rent control, a policy that has been shown to exacerbate the problems it is intended to remedy, and to impose heavy social costs that would not otherwise exist. Nevertheless, the California Supreme Court has declared that it will not strike down rent control under the substantial advancement standard, nor will it apply a heightened level of scrutiny to such regulations.

In response to these rulings, California rental property owners have taken their constitutional claims to federal court. In a series of decisions culminating in Cashman v. City of Cotati, the Ninth Circuit has found rent control laws to violate the Takings Clause under a substantial advancement standard. One of these cases, Lingle v. Chevron, USA, was accepted for review by the United States Supreme Court in October, 2004. The outcome of this case will have major ramifications for rent control and regulatory takings law in the $21^{\text {st }}$ century.
\end{abstract}




\section{TABLE OF CONTENTS}

I. The Once and Future Taking 1

II. California Rental Property Owners Turn to the Federal Courts 6

III. The Politics and Economics of Mobile Home Park

Rent Control

IV. The Capitalization of the Present Value of Rent

Control into Coach Prices Has Been Empirically

Confirmed and Measured

V. Early Takings Challenges to Mobile Home Park Rent Control Applied Loretto's Physical Occupation Analysis

VI. Yee v. Escondido Marked a Transition from Hall's

Physical Takings Theory to Claims Based on Failure to Substantially Advance Legitimate Interests

VII. The next Generation of Rent Control Takings Claims: Richardson, Chevron, and Cashman

VIII. Will the Supreme Court Finally Decide? 


\section{I \\ THE ONCE AND FUTURE TAKING}

A decade ago I took part in a conference at Fordham University Law School, at which I set out the thesis that rent control, as commonly practiced in the United States, violates the Takings Clause of the Fifth Amendment. ${ }^{1}$ The argument was straightforward, and has not changed. Its core rests on the first prong of the Supreme Court's two-part regulatory takings standard, first enunciated in Agins v. City of Tiburon, ${ }^{2}$ that a land-use regulation violates the Takings Clause if it fails to substantially advance legitimate state interests. ${ }^{3}$ I recognize that a handful of commentators have made something of a cottage industry out of arguing that the Court really didn't mean what it said in Agins, or was confused, or somehow misstated the law, such that the substantial advancement test "really" isn't a takings standard at all. ${ }^{4}$ To them I can only say, dream

1 See R. S. Radford, Why Rent Control Is a Regulatory Taking, 6 Fordham Envt'1. L.J. 755 (1995). For an even earlier exposition of the same theme, see R. S. Radford, Regulatory Takings Law in the 1990s: The Death of Rent Control?, 21 Southw. U. L. Rev. 1019 (1992). The Takings Clause provides, “. . . nor shall private property be taken for public use without just compensation.” U.S. CONST. amend. V.

2447 U.S. 255 (1980).

3 Id. at 260.

4 See, e.g., Thomas E. Roberts, Facial Takings Claims under Agins-Nectow: A Procedural Loose End, 24 U. Haw. L. Rev. 623, 639 (2002) ("The entry of the 'substantially advance legitimate state interests' language into the takings lexicon can most charitably be described as a mistake”); Douglas T. Kendall, Timothy J. Dowling \& Andrew W. Schwartz, TAKINGs LiTIGATION HANDBOOK 237 (2000) (“Agins provides no evidence that the Court desired to create an entirely new standard of takings liability."); John D. Echeverria, Does a Regulation That Fails to Advance a Legitimate Governmental Interest Result in a Regulatory Taking?, 29 Envtl. L. 853, 858 (1999) (attributing Supreme Court's adoption of substantial advancement takings test to "an inadvertent muddling of legal doctrines"). 
on. ${ }^{5}$ This doctrine is in fact firmly established, has regularly been reiterated, ${ }^{6}$ and has been employed to strike down a variety of land-use regulations, both facially and as applied. ${ }^{7}$ Indeed, the Court went far out of its way to reaffirm the substantial advancement test as a viable regulatory takings standard in the last major takings case to come before it, Tahoe-Sierra Preservation Councilv. Tahoe Regional Planning Agency. ${ }^{8}$ Until the Court says or does something that can reasonably be construed as repudiating the substantial advancement takings standard, I will therefore assume that it remains in effect.

5 For a more nuanced response, see R. S. Radford, Of Course a Land Use Regulation That Fails to Substantially Advance Legitimate State Interests Results in a Regulatory Taking, 15 Fordham Envt'l L. J. 353 (2004).

6 See Tahoe-Sierra Preservation Council v. Tahoe Regional Planning Agency, 535 U.S. 302, 334 (2002); City of Monterey v. Del Monte Dunes at Monterey, 526 U.S. 687, 704 (1999), Dolan v. City of Tigard, 512 U.S. 374, 385 (1994); Lucas v. South Carolina Coastal Council, 505 U.S. 1003, 1016 (1992); Yee v. City of Escondido, 503 U.S. 519, 534 (1992); Keystone Bituminous Coal Assn. v. DeBenedictis, 480 U.S. 470, 485 (1987); Nollan v. California Coastal Commission, 483 U.S. 825, 834 (1987); United States v. Riverside Bayview Homes, Inc., 474 U.S. 121, 126 (1985).

7 See City of Monterey, id.; Dolan, id.; Nollan, id.

8535 U.S. 302 (2002). Although the Tahoe-SierrcCourt found that a temporary development moratorium could not effect a categorical taking under Lucas v. South Carolina Coastal Council, 505 U.S. 1003, Justice Stevens' majority opinion went on to explain that such a moratorium could give rise to liability as a regulatory taking under any of seven alternative theories, including the following:

[A]part from the District Court's finding that TRPA's actions represented a proportional response to a serious risk of harm to the lake, petitioners might have argued that the moratoria did not substantially advance a legitimate state interest.

Id. at 334 (emphasis added). 
Complying with this criterion requires that restrictive regulations be designed to mitigate some demonstrable social costs that would otherwise be imposed by the unregulated use of the property in question. ${ }^{9}$ Already in 1995 there existed a mass of uncontroverted empirical evidence demonstrating that rent control tends to have the opposite effect - creating social costs and burdens that would not otherwise exist, and exacerbating housing problems far beyond anything that would pertain in competitive markets. Rent-controlled cities in California and Massachusetts have suffered serious declines in their stock of rental housing, despite a housing boom in comparable but uncontrolled cities in those states. ${ }^{10}$ Moreover, the incidence of these costs has been alarmingly regressive. It has long been understood that a disproportionate share of the financial benefits of rent control accrue to residents of the most well-to-do neighborhoods. ${ }^{11}$ In California, this tendency has been pushed to new heights (or depths, depending on one's social perspective), as the diminishing rental housing stock has

9 See Nollan., 483 U.S. at 838-39. See also, e.g., Molly S. McUsic, Looking Inside Out: Institutional Analysis and the Problem of Takings, 92 Nw. U. L. Rev. 591, 602 (1998):

[The Nollan] Court described the "substantially advance" test as one that examines the proportionate relationship between the amount of public harm caused by the owner and the regulatory burden imposed: a cause-effect test.

10 See Radford, Why Rent Control Is a Regulatory Taking, supra note 1, at 770 (citing research showing that, "[w]hile the regulated cities lost $8 \%$ to $14 \%$ of their rental housing stock, comparable locales without rent control increased their supply of rental units, typically by $5 \%$ to $20 \%$ over the decade.") (emphasis in original).

11 See, e.g., John C. Moorhouse, Long-Term Rent Control and Tenant Subsidies, 27 Q. Rev. Econ. \& Bus. 6, 21 (1987); Ned Levine, et al., Who Benefits from Rent Control?, 56 Am. Plan. Ass'n. J. 140, 144 (1990). 
become occupied by an increasingly white, middle class, professional population of renters. ${ }^{12}$ It is hard to imagine another policy option that could have been more effective in displacing the poor and minorities from such bastions of radical gentrification as Berkeley and Santa Monica, California. ${ }^{13}$

One thing that has changed in the course of the past ten years, however, is that the California Supreme Court has made it unmistakably clear that it just doesn't care. In Santa Monica Beach Ltd. v. Superior Court,${ }^{14}$ a regulatory taking challenge to Santa Monica's rent control scheme, the state's high court proclaimed that, contrary to the United State Supreme Court's requirement of heightened scrutiny in such cases,${ }^{15}$ it would apply the most deferential possible standard of review. If a human being can be located, anywhere on the face of the earth, who can imagine any possible rationale for adopting such a law, it will pass constitutional muster in California. ${ }^{16}$ And just to be on the safe side, the state court added (in a separate decision) that the constitutionally required remedy of just compensation would not be available, even if a violation of the Takings Clause were somehow established. Under the doctrine laid down in Kavanau v.

${ }^{12}$ See St. John \& Associates, Rent Control in Perspective: Impacts on Citizens and Housing in Berkeley and Santa Monica Twelve Years Later (August, 1993).

${ }^{13}$ See id.

14968 P.2d 993 (Cal. 1999).

15 See Nollan, 483 U.S. at 834 n.3.

${ }^{16}$ See Santa Monica Beach, 968 P.2d at 1002. 
Santa Monica Rent Control Board ${ }^{17}$ the only remedy California courts can grant for being deprived of one's property by a predatory rent control board is the right to ask them to please give it back. ${ }^{18}$ Certainly, being required to return to an agency that has violated your constitutional rights and ask them to reconsider seems more like a remedy for a due process violation than for a taking. The California Supreme Court agrees but is not bothered by that fact, since it has determined that "a remedy for [a] due process violation, if available and adequate, obviates a finding of a taking., ${ }^{19}$ Because every takings claimant was already required, under California's unique procedural scheme, to obtain a due process remedy as a prerequisite to pursuing inverse condemnation, ${ }^{20}$ and under Kavanau a due process remedy obviates the finding of a taking (and therefore moots any inverse condemnation claim), the California Supreme Court has effectively foreclosed inverse condemnation as a remedy in all cases alleging a regulatory taking by operation of a rent control law. ${ }^{21}$

17941 P.2d 851 (Cal. 1997).

18 The Kavanau court established that the only recourse for property owners who have been subjected to confiscatory rent regulations is to seek to have the rent board's actions invalidated via mandamus, followed by a return to the offending agency for further proceedings. See id. at 865 .

${ }^{19} I d$. at 865 (emphasis added).

${ }^{20}$ See Hensler v. City of Glendale, 876 P.2d 1043, 1056-60 (Cal. 1994) (holding that all regulatory takings claims in California courts must proceed by way of administrative mandamus or declaratory relief).

${ }^{21}$ See, e.g., Galland v. City of Clovis, 16 P.3d 130, 134 (Cal. 2001) (Kavanau "precluded a claim for inverse condemnation"). 
It remains true today, as it was a decade ago, that the United States Supreme Court has never upheld a peacetime rent control law challenged as a regulatory taking, ${ }^{22}$ and in fact struck down one such measure in the formative years of its regulatory takings jurisprudence. ${ }^{23}$ Elsewhere at the state level, New York's highest tribunal has found a rent control law to be unconstitutional under the substantial advancement inquiry. ${ }^{24}$ In California, however, rental property owners have learned that they will have to look elsewhere than to the state court system to pursue legal claims stemming from violations of their Fifth Amendment rights.

\section{II CALIFORNIA RENTAL PROPERTY OWNERS TURN TO THE FEDERAL COURTS}

Following the Kavanau and Santa Monica Beach decisions, California property owners began turning to the federal judiciary, which might reasonably be presumed to offer a more stalwart defense of rights guaranteed under the federal Constitution. Indeed, a takings challenge to a mobile home park rent control law had already met with success in the Ninth Circuit, ${ }^{25}$ albeit under a somewhat strained legal theory. ${ }^{26}$ Nevertheless, the shift from state to federal court as the preferred locus of rent control litigation has not

22 See Radford, Why Rent Control Is a Regulatory Taking, supra note 1, at 762-64.

23 See Chastleton Corporation v. Sinclair, 264 U.S. 543, 547-48 (1924).

24 See Manocherian v. Lenox Hill Hospital, 643 N.E. 2d 479, 483-84 (N.Y. 1994).

25 See Hall v. City of Santa Barbara, 797 F.2d 1493, amended on denial of rehearing and rehearing en banc, 833 F.2 1270 (9th Cir. 1986).

26 See infra, text at notes 74-83. 
been a seamless transition. A host of procedural pitfalls have presented themselves, many of which are still being litigated at this time. ${ }^{27}$

In the Ninth Circuit, regulatory takings claims must be brought under 42 U.S.C. $\S$ $1983,{ }^{28}$ and the Supreme Court has tied the statute of limitations for $\S 1983$ actions to the applicable state's statute for personal injury claims. ${ }^{29}$ At the time of Kavanau and Santa Monica Beach, this set a one-year limitation period for bringing takings claims in federal court. ${ }^{30}$ No new apartment rent control ordinances have been adopted in California since the 1980s, so facial takings challenges to these measures cannot be brought in federal court unless they are significantly amended. On the other hand, scores of California jurisdictions have imposed rent control on mobile home parks over the past decade, and these laws continue to be adopted throughout the state. For this reason, all facial takings challenges to rent control laws filed in the federal courts of California since Kavanau and Santa Monica Beach have been brought by the owners of mobile home parks.

A far more serious stumbling block has been the "ripeness" doctrine of Williamson County Regional Planning Commission v. Hamilton Bank of Johnson City. ${ }^{31}$

27 See, e.g., Carson Harbor Village, Ltd., v. City of Carson, 353 F.3d 824 (9th Cir. 2004) (petition for certiorari pending); Hacienda Valley Mobile Estates v. City of Morgan Hill, 353 F.3d 651 (9th Cir. 2003) (same); San Remo Hotel v. City and County of San Francisco, 364 F.3d 1088 (9th Cir. 2004) (same).

28 See Azul-Pacifico, Inc., v. City of Los Angeles, 973 F.2d 704, 705 (9th Cir. 1992).

29 See Wilson v. Garcia, 471 U.S. 261 (1985).

30 The California statute of limitations was increased to two years in 2002. See Calif. Code Civ. Proc. $§ 335.1$.

31473 U.S. 172 (1985). 
In Williamson County, the Supreme Court held that, to ripen a regulatory takings claim for adjudication in federal court, the plaintiff must first have sought "compensation through the procedures the State has provided for doing so." 32 Since this requirement applies only when the state makes available "reasonable, certain, and adequate" procedures for obtaining just compensation for a taking, ${ }^{33}$ California rental property owners have understandably argued that pursuing a state claim would be futile, given the California courts' foreclosure of a compensation remedy in Kavanau. To date, the Ninth Circuit has been reluctant to accept this argument in cases challenging the unconstitutional application of rent regulations. ${ }^{34}$ But the courts of that Circuit apply a different rule where a plaintiff brings a facial takings challenge based on a failure to substantially advance legitimate state interests. In this situation, Williamson County's state procedures requirement does not apply, because such a claim "does not depend on the extent to which [landowners] are deprived of the economic use of their ... property.",35

32 Id. at 194.

33473 U.S. at 194.

34 See, e.g., Carson Harbor Village, 353 F.3d at 829-30; Hacienda Valley Mobile Estates, 353 F.3d at 659-60.

35 Sinclair Oil Corp. v. County of Santa Barbara, 96 F.3d 401, 406 (9th Cir. 1996), quoting Yee v. City of Escondido, 503 U.S. at 534. See also San Remo Hotel v. City and County of San Francisco, 145 F.3d 1095, 1102 (9th Cir. 1998) (stating that a facial takings claim based solely on the allegation that an ordinance did not substantially advance legitimate interests is immediately ripe for federal adjudication). 
Other procedural hurdles have of course been raised by local governments in California to try to bar federal takings claimants from seeking relief in federal court. ${ }^{36}$ In general, though, the relatively short statute of limitations is the determinative procedural issue for asserting federal jurisdiction over facial "substantial advancement" claims.

\section{III \\ THE POLITICS AND ECONOMICS OF MOBILE HOME PARK RENT CONTROL}

At a sufficient level of abstraction, the political economy of all rent control is the same. When government can be induced to set rents below market levels, an identifiable quantum of real wealth is shifted from the owners of the regulated property to their tenants. ${ }^{37}$ If the per capita value of this wealth transfer exceeds the opportunity costs of lobbying, rational tenants will lobby for the adoption of rent control..$^{38}$ This is a commonplace example of the process Madison warned against as the employment of governmental power for the benefit of "factions": ${ }^{39}$

36 See, e.g., Montclair Parkowners Association v. City of Montclair, 264 F.3d 829 (9th Cir. 2001) (district court invoked Younger abstention to avoid exercising jurisdiction over mobile home rent control takings claim); San Remo Hotel v. City and county of San Francisco, 364 F.3d 1088 (district court invoked claim and issue preclusion after state claims had been litigated in state court in compliance with Williamson County).

37 See, e.g., Armen Alchian \& William R. Allen, Exchange and Production 93-96 (2d ed. 1977); ANTHONy Downs, RESIDENTIAL RENT CONTROLS: An Evaluation 55-60 (1988).

38 See generally, e.g., Mancur Olson, The Logic of Collective ACtion (1965); Anne O. Krueger, The Political Economy of the Rent-Seeking Society, 64 Amer. Econ. Rev. 291 (1974).

39 See The Federalist No. 10, at 778 (James Madison) (Clinton Rossiter ed., 1961) (cautioning against the influence of "factions," i.e,, "a number of citizens, whether amounting to a majority or minority of the whole, who are united and actuated by some (continued) 
The first danger in any democracy is the most readily understood. Majorities use their power to take away resources and opportunities from minorities and redistribute it to themselves. ${ }^{40}$

Rent control in mobile home parks, however, adds a powerful "kicker" not found in other varieties of rent regulation: once tenant-lobbyists have succeeded in imposing controls, they can immediately "cash out," capturing the full present value of below-market rents by selling their mobile home coach in place in a rent-controlled park. ${ }^{41}$

Mobile home park tenants normally own their own coaches, which sit on land (spaces commonly referred to as pads) owned by the mobile home park. Their housing costs are therefore the sum of mortgage payments on the coach, plus rent payments on the underlying land. Rent control obviously reduces the second component, but in addition, the assurance of below-market rents in the future is capitalized into the resale value of the coach. This "premium," or incremental resale value attributable to rent control, represents the present value of the future stream of financial benefits tenants will receive

common impulse of passion, or of interest, adverse to the rights of other citizens, or to the permanent and aggregate interests of the community").

40 John O. McGinnis, Public Choice and the Structural Constitution: the Original Constitution and its Decline: a Public Choice Perspective, 21 Harv. J.L. \& Pub. Pol'y 195, 197 (1997).

41 See, e.g. Richard A. Epstein, Yee v. City of Escondido: The Supreme Court Strikes Out Again, 26 Loyola of Los Angeles Law Review 3, 10 (1992) (Mobile home park rent control " increases the returns to local renters from the passage of the rent control statute by allowing them to capture the full stream of future periodic expropriations from the landlord. That larger rate of return gives the renters a greater inducement for the passage of the rent control statute in the first place, and thus increases the likelihood that such a statute will be passed."). 
from the regulations, discounted at an appropriate rate. ${ }^{42}$ It is an amount equal to the decrease in value of the underlying land because of rent control, ${ }^{43}$ and therefore is the equivalent of a direct cash transfer from park owner to tenant, effected via the legislative process. $^{44}$

The financial stakes for California park tenants are large enough that (unlike apartment residents) they have organized a powerful statewide lobbying organization dedicated to securing and maintaining these wealth transfers. ${ }^{45}$ One early victory was the passage of California's Mobilehome Residency Law ${ }^{46}$ which among other things virtually eliminates the park owners' ability to approve or disapprove potential buyers of coaches installed in their parks. ${ }^{47}$ This state law, in conjunction with local rent control, relegates park owners to the role of more or less passive observers, while their tenants

42 It should go without saying that this is a market process that will occur even if coach owners themselves are incapable of estimating the variables.

43 See, e.g., Werner Z. Hirsch \& Joel C. Hirsch, Legal-Economic Analysis of Rent Controls in a Mobile Home Context: Placement Values and Vacancy Decontrol, 35 UCLA L. Rev. 399, 423-24 (1988).

44 Despite a superficial similarity, rent control's inverse impact on the prices of coaches and pads does not imply that these are complementary goods (like popcorn and popcorn poppers, in the colorful but economically uninformed analysis of the California Court of Appeal in Yee v. City of Escondido, 224 Cal.App.3d 1349 (1990).

45 This is the Golden State Mobilehome Owners League (GSMOL). For an account of GSMOL's leading role in California rent control politics, see William A. Fischel, Exploring the Kozinski Paradox: Why Is More Efficient Regulation a Taking of Property?, 67 Chi.-Kent. L. Rev. 865, 895-97 (1991). In recent years a second, smaller lobbying group has split off from GSMOL and conducts parallel lobbying activities.

46 Cal. Gov. Code $\S \S 798$ et seq.

47 See id., $§ \$ 798.70$ - 798.73. 
buy and sell the capitalized value of living in their parks under rent control. ${ }^{48}$ This also provides a telling illustration of the unavailability of "exit" as an option for park owners who wish to protect their assets from regulatory depredation. ${ }^{49}$

\section{IV \\ THE CAPITALIZATION OF THE PRESENT VALUE OF RENT CONTROL INTO COACH PRICES HAS BEEN EMPIRICALLY CONFIRMED AND MEASURED}

Just as the social costs of traditional rent control have been empirically

documented, ${ }^{50}$ so too has the capitalization into coach prices of the monetary value of mobile home park rent control. The first empirical research to identify and measure coach sales premiums attributable to rent control was conducted by Dr. Werner Hirsch, an internationally reputed economist at the University of California, Los Angeles. ${ }^{51}$ In an article published in the Journal of Urban Economics in $1988,{ }^{52}$ Hirsch employed a non-

48 See Hirsch \& Hirsch, supra note 43, at 420-22.

49 See, e.g., Vicki Been, "Exit" as a Constraint on Land Use Exactions: Rethinking the Unconstitutional Conditions Doctrine, 91 Columb. L. Rev. 473 (1991). As Fischel observes, "“[e]xit' has a hollow meaning for people with immovable assets." Fischel, supra note 45 , at 898 .

50 See, e.g., DownS, supra note 37, at17-28; Richard W. Ault, et al, The Effect of Long term Rent Control on Tenant Mobility, 35 J. Urb. Econ. 140 (1994); Steven B. Caudill, et al., Efficient Estimation of the Costs of Rent Controls, 71 Rev. Econ. \& Stat. 154 (1989); Donald F. Vitaliano, Measuring the Efficiency Cost of Rent Control, 14 Am. Real Est. \& Urb. Econ. Ass'n J. 61 (1986).

51 A professor of economics and consultant to the RAND Corporation, Dr. Hirsch is the author of college textbooks in, inter alia, statistics and economic analysis of law. See "Vitae: Werner Z. Hirsch," dated October, 1999, on file with author.

52 Werner Z. Hirsch, An Inquiry into Effects of Mobile Home Park Rent Control, 24 J. Urb. Econ. 212 (1988). This same study formed the basis for a second article appearing in 1988, this one co-authored with attorney Joel C. Hirsch and published in the UCLA (continued) 
linear multiple regression model in which the in-site selling price of California mobile homes was taken as a function of eight independent variables measuring the physical quality of the mobile home coach; the size of the coach; median apartment rents and vacancy rates in the community; the quality of the mobile home park in which the coach was situated; and whether the park was subject to rent control. ${ }^{53}$ Hirsch's data base consisted of 333 sales of mobile homes in 40 California communities in 1984-86. ${ }^{54}$ Twelve of these cities had enacted rent control; the remaining 28 had not. ${ }^{55}$ This study found that coach resale prices were significantly higher in communities that had adopted rent control. Hirsch concluded, "It appears that capitalization of restrictions on rent increases into sales prices is substantial." ${ }^{56}$ Specifically, "sales prices were on average about $\$ 8,800$ or $32 \%$ higher in communities that had imposed rent control. ${ }^{57}$

In 1993, Hirsch conducted another study of sales in a single upper-end California park, the Laguna Vista Mobile Home Park in Oceanside, California. ${ }^{58}$ In this study Hirsch applied a hedonic regression model to 60 sales that occurred in the park over a six-

Law Review. See Hirsch \& Hirsch, supra, note 43.

${ }^{53}$ See Werner Z. Hirsch, An Inquiry into Effects of Mobile Home Park Rent Control, id., at 223.

${ }^{54}$ See id. at 220.

${ }^{55}$ See id.

${ }^{56} I d$. at $223-24$.

${ }^{57}$ Id. at 224.

58 See Werner Z. Hirsch \& Anthony M. Rufolo, The Regulation of Immobile Housing Assets under Divided Ownership, 19 Int'l Rev. L. \& Econ. 383, 395 (1999). 
year period in which slightly more than $60 \%$ of the park's pads were subject to rent control, while the remainder were exempt. ${ }^{59}$ Over this period, Hirsch found that "sales prices of mobile homes under rent control were $\$ 3,531$, or $8 \%$, higher than prices for the uncontrolled ones." 60

In 2002, Dr. John Quigley of the University of California, Berkeley, conducted a study of the impact of rent control in the Contempo Marin Mobile Home Park in San Rafael, California. ${ }^{61}$ Quigley took two different approaches to the question, estimating both the magnitude of the financial benefits that were captured by park tenants, and the cost of the regulations to the park's owners in the form of depressed land values. For purposes of estimating the premium in coach values attributable to rent control, Quigley's database consisted of 40 sales of coaches in Contempo Marin over a 39-month period. ${ }^{62}$ The resale prices of these coaches were compared to their estimated "blue book" values in the NADA Mobile/Manufactured Housing Appraisal Guide, adjusted for individual quality factors as determined by an independent appraiser. ${ }^{63}$ On average, Quigley found a capitalized premium of almost $\$ 61,000$ per coach created by San Rafael's rent control

59 See id.

60 Id. at 396.

61 See John M. Quigley, Economic Analysis of Mobile Home Rent Control: The Example of San Rafael, California (September 12, 2002) (unpublished report on file with author).

62 See id. at $15-16$.

63 See id. 
ordinance. ${ }^{64}$ This amounted to two-thirds of the resale price of the coaches; ${ }^{65}$ looked at differently, park tenants realized markups in the sales prices of their coaches averaging $366 \%$ as a direct consequence of rent control. ${ }^{66}$

Turning to the cost side, Quigley constructed two different hedonic pricing models to estimate the value of the land underlying mobile homes in the Contempo Marin park. Comparing the annualized market value to the land rents allowed under the rent control law, Quigley determined that the ordinance reduced the value of the park owner's land by an average of $\$ 7,400$ to $\$ 8,200$ per mobile home per year, depending on the model. ${ }^{67}$ Quigley also established that the tenants in occupancy at the time rent control was imposed captured virtually the entire benefit of future controlled rents through capitalizing this value into the resale price of their coaches:

"[E]ssentially all of the annual benefits arising from lower rents are offset by increases in carrying costs. Conversely, we find clear evidence that the removal of these price controls would have no adverse effects upon the affordability of these dwelling units to incoming residents - certainly not their affordability to low income households in the local housing market." ${ }^{, 68}$

\footnotetext{
64 See id. at 17.

65 See id.

66 See id.

67 See id. at 23.

${ }^{68} I d$. at 2 .
} 
The most recent research on this topic is currently being conducted at the University of Southern California, where urban economists are examining a 20-year time series of mobile home resale prices from seven California counties. ${ }^{69}$ Consistent with previous studies, this research has found that resale price increases for coaches in rentcontrolled parks outpaced comparable units in uncontrolled jurisdictions by 17 percentage points, a difference the researchers attributed to capitalization of the value of rent control. $^{70}$

\section{$\mathbf{V}$ \\ EARLY TAKINGS CHALLENGES TO MOBILE HOME PARK RENT CONTROL APPLIED LORETTO'S PHYSICAL OCCUPATION ANALYSIS}

As is apparent from the foregoing empirical studies of the capitalization process, the magnitude of the aggregate wealth transfers that rent control can facilitate within a single mobile home park can be substantial. This, coupled with the effect of the Mobilehome Residency Law in depriving park owners of any meaningful control over who occupies their property, led the first wave of constitutional challenges to be modeled on the "permanent physical occupation" theory of Loretto v. Teleprompter Manhattan CATV Corp. ${ }^{71}$ This would ultimately prove to be a poor strategy, but it met with initial success in the Ninth Circuit.

69 See David Dale-Johnson, et al, An Examination of the Impact of Rent Control on Mobile Home Prices in California (draft final report dated October 11, 2004, on file with author).

70 See id. at 15.

71458 U.S. 419 (1982). In Loretto, the Court established that "a permanent physical occupation authorized by government is a taking without regard to the public interests that it may serve." Id. at 426. 
In Hall v. City of Santa Barbara ${ }^{72}$ the Ninth Circuit reversed a trial court's order

upholding the city's mobile home park rent control against the park owners' Loretto

claim. The court accurately characterized the owners' takings claim as "novel:",73

[The Halls] argued that by giving tenants the right to a perpetual lease at a belowmarket rental rate, the ordinance transfers to each of them a possessory interest in the land on which their mobile home is located. According to the Halls, this interest has a market value and a market: the market for mobile homes located in mobile home parks. According to the Halls, the price of mobile homes in their park shot up dramatically after enactment of the ordinance, with many selling far above their blue book value. They claim that the substantial premium paid for mobile homes in parks subject to the Santa Barbara Ordinance reflects the transfer of a valuable property right to occupy mobile home parks at below-market rates. ${ }^{74}$

Briefly reviewing the distinction between regulatory takings and takings by physical occupation, ${ }^{75}$ Judge Kozinski's unanimous opinion observed that,

Reduced to its essentials, appellants' claim is that the Santa Barbara ordinance has transferred a possessory interest in their land to each of their 71 tenants; that this interest consists of the right to occupy the property in perpetuity while paying only a fraction of what it is worth in rent; and that this interest is transferable, has an established market and a market value. If proven, appellants' claims would amount to the type of interference with the property owner's rights the [Supreme] Court described so eloquently in Loretto. $^{76}$

For reasons that have never been explained, the Hall panel followed this analysis with an inquiry into whether Santa Barbara's ordinance substantially advanced legitimate

72833 F.2d 1270 (9th Cir. 1986).

${ }^{73}$ Id. at 1273 .

${ }^{74} \mathrm{Id}$. at $1273-74$.

${ }^{75}$ See id. at 1275-76.

${ }^{76}$ Id. at 1276. 
state interests ${ }^{77}$ - even though this inquiry is relevant only to regulatory takings claims, and had not been raised in the Halls' complaint. Because new tenants would receive no financial benefit from rent control, having paid its full cash value to the previous coach owners, the Hall court found that the law "may well hinder" ${ }^{\text {"78 }}$ its objective of alleviating a "critical shortage of low and moderate income housing.,"79 Nevertheless, the opinion concludes by characterizing the plaintiffs' claims exclusively in terms of the physical taking theory that had been alleged and argued in the District Court. ${ }^{80}$

Judge Shroeder, in an energetic dissent from the Ninth Circuit's subsequent denial of rehearing en banc, focused primarily on the inapplicability of Loretto's physical occupation analysis to the facts of Hall. Noting that Loretto was limited by its own terms to situations involving an "actual appropriation of the land itself through physical contact," ${ }^{81}$ Judge Schroeder rejected the Hall panel's premise that "economic regulation can 'shade' into physical invasion. ${ }^{, 82}$ The dissent concluded by lamenting:

Although [the panel opinion] is not a decision on the merits invalidating any ordinance, it is an authorization for broad, wholesale attacks upon rent control regulation. It casts a shadow upon all economic regulation. Our court must now

${ }^{77}$ See id at 1280-81.

${ }^{78}$ Id. at 1281 .

${ }^{79} I d$. at $1280-81$.

${ }^{80}$ See id.

${ }^{81}$ Id. at 1283.

${ }^{82} I d$. (citation omitted). 
sit idly by and watch taxpayers' money and court time being expended in litigation over the effects of this decision. ${ }^{83}$

In this, Judge Schroeder proved to be half right. Hall indeed marked the opening skirmish in a protracted battle over the constitutionality of mobile home rent regulations that would continue into the next century. However, the Ninth Circuit would hardly "sit idly by" as an observer in this process.

\section{VI \\ YEE V. ESCONDIDO MARKED A TRANSITION FROM HALL'S PHYSICAL TAKINGS THEORY TO CLAIMS BASED ON FAILURE TO SUBSTANTIALLY ADVANCE LEGITIMATE INTERESTS}

The successful Hall litigation triggered a flurry of lawsuits challenging the constitutionality of mobile home rent control in California. ${ }^{84}$ Unfortunately for the plaintiffs, Williamson County was at that point forcing such cases into state court, where they were summarily dispatched by an unsympathetic judiciary. ${ }^{85}$ Finally in 1992 , one such Hall follow-up action, Yee v. City of Escondido, ${ }^{86}$ was accepted for review by the United States Supreme Court.

${ }^{83} I d$.

84 See, e.g., DeAnza Properties X, Ltd., v. County of Santa Cruz, 936 F.2d 1084 (9th Cir. 1992); Azul-Pacifico, Inc., v. City of Los Angeles, 973 F.2d 704.

85 At the time Hall was filed, the California Supreme Court expressly foreclosed just compensation as a remedy for regulatory takings. In 1987, the United States Supreme Court repudiated this doctrine in First English, and the federal judiciary has since then adhered to the somewhat naive belief that California would follow the High Court's mandate. As noted above, it has not. See supra, text at notes 14-24.

86503 U.S. 519. 
Ignoring the idiosyncratic analysis of the California appeals court, ${ }^{87}$ Justice O'Connor's majority opinion focused on the legal-theoretical shortcomings of applying the Loretto physical takings model to rent control. The standard in such cases, the majority noted, is whether the government "requires the landowner to submit to the physical occupation of his land, ${ }^{, 88}$ which the Court did not believe to be the situation in Yee. The Court recognized and addressed the effect of Escondido's ordinance in enabling tenants to capitalize the monetary value of the regulations into the resale price of their coaches:

Mobile homes, like motor vehicles, ordinarily decline in value with age. But the effect of the rent control ordinance, coupled with the restrictions on the park owner's freedom to reject new tenants, is to increase significantly the value of the mobile home. This increased value normally benefits only the tenant in possession at the time the rent control is imposed. See Hirsch \& Hirsch, 35 UCLA L. Rev., at 430-431. Petitioners are correct in citing the existence of this premium as a difference between the alleged effect of the Escondido ordinance and that of an ordinary apartment rent control statute. ${ }^{89}$

Yet, while acknowledging that such an explicit majoritarian wealth transfer might fall "within the scope of our regulatory taking cases," $" 90$ the Court rejected the park owners' argument that the tenants' capture of the value of occupying the plaintiffs' property

${ }^{87}$ For a critique of some of the flaws in Justice Wiener's opinion for the Fourth District Court of Appeal, see Fischel, supra note 45, at 903-906.

${ }^{88} 503$ U.S. at 527.

${ }^{89} I d$. at 530.

${ }^{90} \mathrm{Id}$. 
effected a physical taking. ${ }^{91}$ Perhaps most significantly, Justice O'Connor went on to add:

This effect might have some bearing on whether the ordinance causes a regulatory taking, as it may shed some light on whether there is a sufficient nexus between the effect of the ordinance and the objectives it is supposed to advance. ${ }^{92}$

This is, of course, a reference to the substantial advancement takings standard, already cied as an alternative basis for takings liability in Hall $^{93}$ Yet despite the urging of Judge Bork's brief for the petitioners ${ }^{94}$ and an amicus brief filed in their support, ${ }^{95}$ the Court declined to consider the merits of a regulatory takings claim in Yee, on the technical grounds that this question had not been presented in the Yees' petition for certiorari. ${ }^{96}$

As Judge Kozinski put it, Yee sent Hall'sphysical -taking rationale "to that purgatory where all discredited legal theories go, waiting to be given new life by a more enlightened Supreme Court."97 But on the other hand, as was immediately recognized in

91 Id. at 526-30.

92 Id. at 530, citing to Nollan, 483 U.S. at 834-35.

93 See Hall, 833 F.2 at 1280-81.

94 See Yee v. City of Escondido, No. 90-1947, Brief for Petitioners, Nov. 27, 1991, at 2530 (arguing that Escondido's mobile home rent control ordinance failed to substantially advance legitimate state interests under Agins).

95 See Yee v. City of Escondido, No. 90-1947, Brief Amicus Curiae of Pacific Legal Foundation in Support of Petitioners.

96503 U.S. at 533.

97 Judge Alex Kozinski, Who Gives a Hoot about Legal Scholarship?, 37 Hous. L. Rev. 295, 303 (2000). 
the legal literature, ${ }^{98}$ the Court had virtually issued an engraved invitation for park owners to pursue identical claims under Agins' substantial advancement standard.

\section{VII \\ THE NEXT GENERATION OF RENT CONTROL TAKINGS CLAIMS: RICHARDSON, CHEVRON, AND CASHMAN}

The first response to Yee's invitation did not involve mobile home parks at all.

Rather, the property owners in Richardson v. City and County of Honolulu ${ }^{99}$ successfully challenged a condominium rent control law as violating the substantial advancement standard. As is the case with mobile home parks, there is normally divided ownership of condominiums on Oahu and the underlying land. ${ }^{100}$ The ordinance at issue in Richardson limited land-rent increases and specifically provided that the below-market rents were transferable, thereby facilitating capitalization of the financial benefits of rent control by condominium residents. ${ }^{101}$ As in the analogous case of mobile home parks, the Ninth Circuit recognized that "[i]ncumbent owner occupants who sell to those who intend to

98 See, e.g., Kari Anne Gallagher, Comment, Will Mobile Homes Provide an Open Road for the Nollan Analysis?, 67 Notre Dame L. Rev. 821, 848 (1992) ("Evaluated according to the $[$ Agins $]$ analysis, the Escondido ordinance works a taking of private property without just compensation. The Escondido ordinance does not substantially advance legitimate state interests, and it requires mobile home park owners to bear the burden of curing a social problem that they did not create. Therefore, the ordinance, evaluated under [Agins], violates the Fifth Amendment.”); Dwight C. Hirsh IV, Casenote, Yee v. City of Escondido--A Rejection of the Ninth Circuit's Unique Physical Takings Theory Opens the Gates for Mobile Home Park Owners' Regulatory Takings Claims, 24 Pac. L.J. 1681, 1725 (1993).

99 124 F.3d 1150 (9th Cir. 1997).

${ }^{100}$ See id. at 1163.

${ }^{101}$ Id. at 1163-64. 
occupy the apartment will charge a premium for the benefit of living in a rent controlled condominium"102 Drawing on Yee, the court of appeals went on to note that this feature of the ordinance prevented it from substantially advancing legitimate governmental interests:

The conveyance provision, as explained above [facilitating the capitalization and capture of the monetary benefits of rent control], vitiates the cause-and-effect relationship between the property use restricted (rent rates) and the social evil the Ordinance seeks to remedy (lack of affordable housing). ${ }^{103}$

The same analysis was subsequently applied in Chevron U.S.A. Inc. v. Cayetano (Chevron I), ${ }^{104}$ a case in which Chevron alleged that restrictions on the rent it could charge lessee dealers of retail service stations violated the Takings Clause. The District

${ }^{102}$ Id. In striking down the Honolulu ordinance on summary judgment, the Federal District Court in Richardson made the resemblance to mobile home park rent control even more explicit:

Like mobile home park tenants, owner-occupants of leasehold condominiums own their housing unit ... but lease the underlying land. Moreover, the below-market rate lease rent which applies to the mobile home tenants and leasehold condominium owner-occupants is transferable to a subsequent purchaser of the mobile home pad or condominium. With respect to both mobile homes and condominiums, the availability of a below-market rate lease rent necessarily increases the value of the subject housing unit, thereby allowing a seller to command a premium upon the sale of the housing unit.

Richardson v. City and County of Honolulu, 802 F. Supp. 326, 338 (D. Haw. 1992) (emphasis added).

103 Id. at 1165.

104224 F.3d 1030 (9th Cir. 2000). 
Court agreed with Chevron that the regulations enabled incumbent dealers to capitalize the monetary value of reduced rents by selling their dealerships. ${ }^{105}$ The court explained:

[t]he existence of the rent cap makes an independent dealer's leasehold interest in a service station more valuable, and this added value becomes especially significant when an incumbent dealer undertakes to sell his interest. ... Since the Act does not prohibit an incumbent dealer from selling his or her service station lease, the rent cap provision enables these dealers to sell their stations at a premium. ${ }^{106}$

On appeal, the Ninth Circuit found that summary judgment had been improperly granted because of the existence of conflicting expert testimony on whether the premium created by the regulations could be capitalized and captured by the dealers, or whether Chevron could offset this effect by adjusting the wholesale price of its gasoline. ${ }^{107}$ At this point the factual dispute in Chevron diverges from the mobile home park paradigm, since in the latter case there is no possibility of a secondary, offsetting revenue flow between owners and tenants. Nevertheless, Chevron I is important because of its strong reaffirmation of the appropriateness of the substantial advancement standard in takings claims of this kind, ${ }^{108}$ and its acknowledgment that reviewing courts must examine the

105 See Chevron v. Cayetano, 57 F. Supp. 2d 1003, 1010 (D. Haw. 1998).

${ }^{106} I d$.

107 See 224 F.3d at 1037-1040.

108 See id. at 1034-37. "In sum, we disagree with the concurrence's position that we should apply the 'reasonableness' test to evaluate Chevron's regulatory takings claim. The correct test is 'whether the legislation substantially advances a legitimate state interest,' as discussed above, as suggested by the Supreme Court in Yee, as used by the district court in this case, and as established by this court in Richardson." Id. at 1037. 
actual effects of such laws under a heightened level of scrutiny, rather than deferring to statements of legitimate legislative intent. ${ }^{109}$

On remand, the District Court again found that Hawaii's service station rent control scheme violated the Takings Clause. ${ }^{110}$ Twelve years to the day after Yee was decided, the Ninth Circuit affirmed in Chevron v. Lingle (Chevron II), ${ }^{111}$ once again applying the substantial advancement standard to find the rent statute unconstitutional on its face. ${ }^{112}$ Covering much the same ground it had in Chevron I, the court of appeals again drew on Yee and Richardson as teaching

"that application of the 'substantially advances' test is appropriate where a rent control ordinance creates the possibility that an incumbent lessee will be able to capture the value of the decreased rent in the form of a premium.",113

The panel carefully considered and rejected a panoply of new arguments the state leveled against the use of this analysis, ${ }^{114}$ and rebuffed the government's plea for deferential review by noting that this option had been "specifically reject[ed]" by the Supreme Court in Nollan. ${ }^{115}$

109 See id. at 1033-34 (rejecting the State of Hawaii's argument that "courts should look only to whether 'the Legislature rationally could have believed the Act would substantially advance a legitimate government purpose."').

110 See Chevron v. Cayetano. 198 F. Supp.2d 1182 (D. Haw. 2002).

111363 F.3d 846 (9th Cir. 2004).

112 See id. at 857-58.

113 Id. at 849.

114 Id. at $850-53$.

115 Id. at 854 (citing Nollan, 483 U.S. at 825 n.3). 
Together, the two Chevron decisions and Richardson firmly established that rent control ordinances that enable tenants to capitalize the cash value of the regulations into the resale price of an asset will be closely evaluated under the substantial advancement standard in the Ninth Circuit. This set the stage for the first regulatory takings challenge to mobile home park rent control to be decided on the merits in federal court.

In 1997, the California Court of Appeal had reversed the dismissal of a takings claim against the City of Cotati's general rent control law, setting the stage for a trial on the merits. ${ }^{116}$ Instead of proceeding to trial, the city agreed to settle the lawsuit contingent upon an unqualified repeal of the ordinance by the city's voters. But no sooner had the electorate voted to remove rent control from the books, than the city council adopted a new measure that applied rent control exclusively to mobile home parks. The city's three park owners, ${ }^{117}$ feeling that they had unfairly been singled out by the new law, filed suit under a Richardson-style substantial advancement takings theory. This case, Cashman v. City of Cotati, ${ }^{118}$ reached the Ninth Circuit in 2004.

In a decision that closely tracks the legal analysis of Richardson and the two Chevron decisions, the Cashman panel reversed a trial court's ruling that Cotati's new rent ordinance passed constitutional muster, and held that an earlier order granting

${ }^{116}$ See 152 Valparaiso Associates v. City of Cotati, 56 Cal.App.4th 378 (1997).

117 One of the original three plaintiffs, Elizabeth White, sold her park and withdrew as a party to the litigation after the city filed a retaliatory lawsuit against the plaintiffs in state court. See City of Cotati v. Cashman, 52 P.3d 695 (Cal. 2002) (carving out an exception from California's anti-SLAPP statute for municipalities filing such retaliatory litigation).

118374 F.3d 887 (9th Cir. 2004). 
summary judgment to the park owners should be reinstated. ${ }^{119}$ The panel noted the case's factual similarity to Richardson, which was also decided on summary judgment:

Like in Richardson, there is no dispute that Ordinance No. 680 does not on its face prevent mobilehome tenants from capturing a premium. There is separate ownership of the mobilehome coaches and the underlying land, controlled rent, and the ability of incumbent tenants to sell their mobilehomes subject to this controlled rent. This creates the possibility of a premium, which undermines the City's interest in creating or maintaining affordable housing. ${ }^{120}$

In contrast, the Cashman court pointed to the absence of extraneous variables such as had been present in Chevron, that could potentially prevent Cotati's tenants from capitalizing and capturing the rent control premium. ${ }^{121}$ It is perhaps noteworthy that the relatively brief majority opinion in Cashman did not find it necessary to present a detailed rationale for its application of the substantial advancement standard and heightened scrutiny. Presumably, after Chevron II, the propriety of that approach in such cases can be considered settled law of the circuit.

On August 3, 2004, the City of Cotati filed a petition with the Ninth Circuit seeking rehearing or rehearing en banc, once again urging rejection of the substantial advancement standard and heightened scrutiny of regulatory takings claims. ${ }^{122}$ Although the city's petition remains pending at this writing, it seems unlikely that a majority of Ninth Circuit judges would be eager to reverse an unambiguous line of circuit precedent

119 See id. at 899.

${ }^{120} I d$.

121 Id. at 898-99.

122 See Cashman v. City of Cotati, No. 03-15066, Petition for Panel Rehearing and Rehearing En Banc, dated August 3, 2004. 
stretching back to Richardson - especially given the absence of any inter-circuit conflict, and the firm grounding of Richardson, Chevron I, Chevron II, and Cashman in a quarter century of Supreme Court precedent.

The simple reality of the matter may be the Ninth Circuit has finally arrived at a state I thought had been reached ten years ago: ${ }^{123}$ the understanding that, under a proper application of Agins' substantial advancement standard and heightened scrutiny, rent control is a regulatory taking.

\section{VIII WILL THE SUPREME COURT FINALLY DECIDE?}

After denying petitions in a long series of rent control cases dating back to its decision in Yee, the Supreme Court in October, 2004, granted certiorari in Chevron II (now denominated Lingle v. Chevron). ${ }^{124}$ The State of Hawaii's petition focused on the Ninth Circuit's application of the substantial advancement test and heightened scrutiny, in effect asking the High Court to revisit an entire line of its regulatory takings jurisprudence, stretching back a quarter century through Nollan, to Agins. Finally, by the summer of 2005, the Supreme Court may clarify the nature of the invitation it held out in Yee: Does the Takings Clause still function as a bulwark of individual sovereignty against majoritarian rent-seeking? Or will the Court follow California in adopting an "anything goes" standard of review? In the realm of judicial review of land-use regulation, Lingle $v$. Chevron may well set the direction for the $21^{\text {st }}$ century.

123 See Radford, Why Rent Control Is a Regulatory Taking, supra note 1.

124 Case No. 04-163, October 12, 2004. 